\title{
Particle size and lime addiction on properties of wood-cement composites produced by the method of densification by vibro compaction
}

\author{
Rafael da Rosa Azambuja ${ }^{1^{*}}$ Vinicius Gomes de Castro ${ }^{2}$ Barbara Talamini Villas Bôas $^{3}$ \\ Carlos Frederico Alice Parchen ${ }^{4}$ Setsuo Iwakiri ${ }^{5}$
}

\author{
${ }^{1}$ Division of Forestry and Natural Resources, West Virginia University, 322, Percival Hall, Po Box 6125, 26506, Morgantown, WV, USA \\ E-mail: rafael.r.azambuja@gmail.com. "Corresponding author. \\ ${ }^{2}$ Departamento de Ciências Vegetais, Universidade Federal Rural do Semi-Árido (UFERSA), Mossoró, RN, Brasil. \\ ${ }^{3}$ Departamento de Construção Civil, Universidade Federal do Paraná (UFPR), Curitiba, PR, Brasil. \\ ${ }^{4}$ Departamento de Engenharia Civil, Universidade Federal do Paraná (UFPR), Curitiba, PR, Brasil. \\ ${ }_{5}^{5}$ Departamento de Engenharia e Tecnologia Florestal, Universidade Federal do Paraná (UFPR), Curitiba, PR, Brasil.
}

ABSTRACT: This paper aimed to evaluate the effects of particle size and the use of lime as a pretreatment of Pinus spp wood particles on the production of wood-cement composites by vibro-compaction densification. Specimens for internal bond and static bending were produced with two different particle sizes: G1, particles that pass through a $4 \mathrm{~mm}$ screen and were retained at $2 \mathrm{~mm}$ screen, and G2, particles that pass through a $2 \mathrm{~mm}$ screen and were retained at $0.84 \mathrm{~mm}$ screen. The use of lime was also tested in two different methods as pretreatment of wood particles: carbonatation of wood particles before being used in the composite mixture; and addition of hydrated lime directly to the composite mixture. Use of larger particles (G1) presented higher values of internal bond and MOR than composites produced with smaller particles (G2). About the pretreatments, the use of hydrated lime resulted in composites with higher density and better internal bond.

Key words: particle sizes, pretreatment, formation method, low-density panels.

Granulometria das partículas e da adição de cal nas propriedades de compósitos madeira-cimento produzidos pelo método de adensamento por vibro compactação

RESUMO: O presente trabalho visou avaliar o efeito da granulometria e do pré-tratamento com cal das partículas de madeira de Pinus spp na confecção de compósitos madeira-cimento moldados pelo método de adensamento por vibro compactação. Foram produzidos corpos-de-prova para teste de ligação interna e flexão estática com duas diferentes granulometrias de partículas: G1, partículas passantes em uma peneira de $4 \mathrm{~mm}$ e retidas em uma de $2 \mathrm{~mm}$, e G2, partículas passantes em peneira de $2 \mathrm{~mm}$ e retidas em $0,84 \mathrm{~mm}$. Também foram testados o uso da cal por dois diferentes métodos como pré tratamento das partículas de madeira: a carbonatação prévia das partículas antes da confecção dos compósitos e o uso da solução de cal hidratada durante o processo de mistura dos ingredientes. O uso de partículas maiores (G1) apresentou maiores valores de ligação interna e modulo de ruptura quando comparados com compósitos produzidos com partículas menores (G2). Quanto ao pré-tratamento, o uso da cal hidratada resultou em compósitos mais densos e com melhores resultados de ligação interna em relação aos demais tratamentos. Palavras-chave: geometria das partículas, pré-tratamentos, métodos de formação, painéis de baixa densidade.

\section{INTRODUCTION}

The use of residues is an increasingly tendency of the forest sector, integrate them once again in the production process to optimize the use of raw materials and reduce the environmental impact (ABRAF, 2010). Forest industries usually have a low yield and generate large amount of residues, from the cut of the tree until the final product. Forest residues left on the field, including bark, branches and tree tops represent around $20 \%$ of the total amount of wood produced.

Wood-cement composites, besides the great potential to be used on construction, also is a material that can use discard wood as an alternative raw material (WOLFE \& GJINOLLI, 1997). However, several factors can contribute to the properties of wood-cement composites, as wood particles geometry and the inhibitor effect that wood extractives can cause to the cement cure.

The size of the wood particles used on production of wood-cement composites can be direct related to the bound between wood and cement, and as consequence of that, to the final product flexural strength (OLORUNNISOLA, 2009). FRYBORT et al. (2008), in their literature review about cement bonded composites, reported previous research that demonstrated the necessity of use larger particles than the ones used in the resin-bonded particleboards. Small size particles can affect the economical viability of the product because the 
cost of reduction is higher and, with higher superficial area, it is required a higher amount of cement.

Related to the possible inhibitor effect to the cement cure caused by the wood extractives, it is recommended the use of chemical additives. Those additives restrict the inhibition and, as consequence, improved wood-cement composite properties. One of the recommended additives is the chlorides group $\left(\mathrm{CaCl}_{2}, \mathrm{FeCl}_{3}\right.$ and $\left.\mathrm{SnCl}_{2}\right)$ that can be mixture to the board at the amount of $4 \%$ related to the cement weight.

However, after it was reported in the middle of last century that chlorides could induce the steel corrosion, several researchers started to evaluate maximum amount of chloride that could be added to the mixture, based on cement weight. This phenomenon still isn't completely understood and there is no general agreement about the limit percentage of chloride that should be applied to the mixture. European and North American countries limited the use of $0.4 \%$ of chloride based on the cement weight (ANGST et al., 2009). According to the standard NBR-6118 (2003), from Brazil, the use of chloride is not allowed in mixture of reinforced or pre-stressed concrete.

An alternative to the chloride pre-treatment is the use of calcium hydroxide $\left(\mathrm{Ca}(\mathrm{OH})_{2}\right)$. DAL RI (2002), studied the addition of hydrated lime into 11 different types of concrete mixtures. For all treatments, the addition of lime resulted in higher compression resistance values.

In the case of wood-cement composites, according to KARADE et al. (2006), there is two possible ways to treat wood particles with calcium hydroxide: 1) immersion into solution followed by particles wash; 2) immersion followed by incorporation of calcium in the wood. The authors reported that the use of particles immersion into $1 \% \mathrm{Ca}(\mathrm{OH})_{2}$, solution for 1 hour was more efficient than the immersion in cold or hot water for cork particles with granules size lower than $1 \mathrm{~mm}$.

One variation of this process was that wood particles can also be immersed into calcium hydroxide solution for 1 hour, but, subsequently should be airdried, without being washed, to promote the particles carbonatation. The carbonatation is the reaction between $\mathrm{Ca}(\mathrm{OH})_{2}$ and $\mathrm{CO}_{2}$ present at the atmosphere that results in $\mathrm{CaCO}_{3}$ compound. Tests made with Pinus spp branches wood and cement composites pretreated that way indicated increasing values of axial compression compared to composites that used washed particles after $\mathrm{Ca}(\mathrm{OH})_{2}$ extraction. The better result could be explained by the mineral cover of the particle surface after the air-dry acted as a physical barring between cement and wood extractives (PARCHEN, 2012).
Considering the necessity of studies about alternative products based on wood, contemplating residue recovery and new process development, the present research aimed to evaluate the influence of particles size from wood residue produced in a forest exploration of Pinus spp. and lime incorporation as an additive to the mechanical properties of woodcement composites produced by vibro-compaction densification method.

\section{MATERIALS AND METHODS}

Branches and logs of Pinus spp. were collected at the Maracanã sawmill, sited at Tunas, Paraná. The residue specific gravity was $440 \mathrm{~kg}$ $\mathrm{m}^{-3}$. The material was kiln-dried to $3 \%$ moisture content and flakes were processed in a hammer mill at the Wood Boards Laboratory/UFPR. The particles were classified in mechanical screens: G1 - particles that pass through $4 \mathrm{~mm}$ sieve and were collected at $2 \mathrm{~mm}$ sieve; G2 - particles that pass through $2 \mathrm{~mm}$ sieve and were collected at $0.84 \mathrm{~mm}$ sieve.

To the particle geometry determination, it was measured the length, wideness and thickness of 500 particles, for each particles size, with a digital caliper. With the average value of these measurements, it was possible to calculate the slenderness ratios (SR), based on the relation between particles length and thickness, and flatness factor (FF), based on the relation between particles wideness and thickness. The superficial area was calculate by the method suggested by MOSLEMI (1974):

$a^{\prime}=\frac{2 \times((\mathrm{t} \times 1)+(\mathrm{w} \times 1)+(\mathrm{t} \times \mathrm{w}))}{1 \times \mathrm{w} \times \mathrm{t} \times \mathrm{d}}$

Where: a' is the superficial area in $\mathrm{cm}^{-2} \mathrm{~g}^{-1}$; $\mathrm{w}$ and 1 are respectively thickness, wideness and length of particles in cm; and dis the wood specific gravity in $\mathrm{g} \mathrm{cm}^{-3}$.

The particles, for both particles size, were submitted to two types of hydrated lime pretreatment. The first particles batch was treated in calcium hydroxide (with $21,3 \%$ of $\mathrm{CaO}$ ) in a 1:1 ratio based on dry wood weight. Particles were air-dried for 7 days. During this period, $\mathrm{Ca}(\mathrm{OH})_{2}$, naturally reacted with $\mathrm{CO}_{2}$ present in the atmosphere to form calcium carbonate $\left(\mathrm{CaCO}_{3}\right)$. After dried, the carbonatated particles had a weight gain of approximately $42 \%$, due to the combination between wood and lime.

The second particles batch was also pretreated in a calcium hydroxide solution (with $21,3 \%$ of $\mathrm{CaO}$ ) in a 1:1 ratio based on dry wood weight. However, the wet particles were used directly on the wood-cement composite manufacture. 
Specimens were produced by vibrocompaction densification method without pressure, as suggested by PARCHEN (2012). The cement used in this experiment was Portland cement type CP-II. Woodcement ratio used was 2:1 (based on dry weight) and the quantity of water used was calculated by the equation: $\mathrm{H}_{2} \mathrm{O}=(\mathrm{C} * 0.4)+(\mathrm{W} *(0.3-\mathrm{WC} \%))$

Where: $\mathrm{C}$ is the cement weight in grams; $\mathrm{W}$ is the wood particles weight in grams; and $\mathrm{WC} \%$ is the water content of wood particles.

For the second batch, which the water present in the calcium hydroxide solution was kept, the amount of water in the alkaline solution was considered inside the total quantity of water used on the mixture to avoid a difference of methodology among batches.

Specimens were produced in wood molds that had the same dimensions required for bending properties (CEN-EN 310, 1993) and internal bonding (CEN-EN 319, 1993). Material deposited on the molds was submitted to the vibro-dynamic compaction, which consisted in the vibration of the mixture in a way that the particles formed the specimens. The process was made in a vibration table equipped with an electric vibrator motor that applied a vertical impact load of $220 \mathrm{~N}$ at 3,000RPM. Bending and internal bonding tests were performed after 28 days, time required to occur the total cure of cement.

The experimental design consisted by six treatments as shown at table 1.

Results were analyzed by the Statgraphics statistic software, where normality tests, covariance adjustment based on specific gravity and average differentiation by Tuckey method at 5\% significance level were made.

\section{RESULTS AND DISCUSSION}

\section{Particles size analysis}

Average values of slenderness ratio and flatness factor were similar for both particles size,

Table 1 - Research experimental design.

\begin{tabular}{lcc}
\hline & Particles size & Pretreatment \\
\hline T1 & $\mathrm{G} 1$ & - \\
T2 & $\mathrm{G} 1$ & $\mathrm{CaCO}_{3}$ \\
T3 & $\mathrm{G} 1$ & $\mathrm{Ca}(\mathrm{OH})_{2}$ \\
T4 & $\mathrm{G} 2$ & - \\
T5 & $\mathrm{G} 2$ & $\mathrm{CaCO}$ \\
T6 & $\mathrm{G} 2$ & $\mathrm{Ca}(\mathrm{OH})_{2}$ \\
\hline
\end{tabular}

Where: G1, particles that pass through $4 \mathrm{~mm}$ sieve and were collected at $2 \mathrm{~mm}$ sieve; G2, particles that pass through $2 \mathrm{~mm}$ sieve and were collected at $0.84 \mathrm{~mm}$ sieve.
G1 and G2, which indicated that particles dimensions were the same, and only the length, wideness and thickness were different (Table 2).

Dimension of the particles was inversely proportional to the superficial area, in other words, bigger particles (G1) had approximately half of superficial area than smaller particles (G2).

\section{Composites physical and mechanical properties}

Effect of treatments on the mechanical properties of the composites was determined by covariance analysis where the specific gravity was considered covariate (Table 3 ).

The lime incorporation, a material that has an average specific gravity around $3,350 \mathrm{~kg} \mathrm{~m}^{-3}$, increased the wood-cement mixture weight and, as consequence, the specific gravity of the composite. Higher average specific gravity value for composites treated by lime were observed only in treatments that used $\mathrm{Ca}(\mathrm{OH})_{2}$. Those composites demonstrated statistic higher values than $\mathrm{CaCO}_{3}$ treated composites, that kept the same specific gravity value as composites without treatment. One possible explanation for this difference between lime treatments specific gravity can be found at the vibro-compaction formation process, the bond between wood particles and $\mathrm{CaCO}_{3}$ could be compromised by the vibration process, which generated mineral sediments and possible loss of material at the bottom of the formation box. The particles size (G1 and G2) didn't affect the specimens specific gravity.

Specimens with the same pretreatment, but with different particles size (T1xT4; T2xT5; and T3xT6), presented statistically difference between internal bound values for all combinations. The internal bound was higher for composites produced with G1 particles. This result is different from the ones reported on literature, that indicated a negative correlation between particle size and internal bond for wood-cement composites produced by the traditional method of plate presses and cement: wood ratio of $3: 1$. When there is pressured applied to the composite formation, small size particles produced composites with less internal voids, and as consequence, better bound between particles (NAZERIAN et al., 2011; ADEFISAN et al., 2012).

Higher the particles superficial area, higher is the necessity of more cement to coating them. That way, composites produced with G2 particles could be lacking bounding material, what resulted in lower internal bonded values than G1 particles composites.

Related to the pretreatments, it could be observed that the use of calcium hydroxide (T3 and T6) produced composites with higher specific gravity than their related control specimens (T1 and 
Table 2 - Particles size variables.

\begin{tabular}{lcccccc}
\hline & Length $(\mathrm{mm})$ & Wideness $(\mathrm{mm})$ & Thickness $(\mathrm{mm})$ & SR & FF & $\mathrm{a}^{\prime}\left(\mathrm{cm}^{2} \mathrm{~g}^{-1}\right)$ \\
G1 & 11.28 & 2.76 & 1.36 & $4.90(0.71)$ & $2.29(0.50)$ & 53.81 \\
G2 & 6.67 & 1.60 & 0.67 & $4.58(0.57)$ & $2.84(0.53)$ \\
\hline
\end{tabular}

Where: G1 and G2, particles size; SR, slenderness ratio; FF, flatness factor; a', superficial area of particles; and (...) coefficient of variance.

T4, respectively). For composites produced with G1 particles, the densification influenced only internal bond values, others mechanical properties didn't show statistically difference from composite $\mathrm{T} 1$.

However, internal bond values of composites produced with G2 particles and treated with $\mathrm{CaCO}_{3}$ (T5) was statistically different from the others treatments. This comportment wasn't seen at composites produced with G1 particles. Besides the low amount of water to promote the total cure of cement in T6 treatment, another possible explanation was the chemical reaction on the mixture. The reaction between lime and wood can partially degrade hemicelluloses and form soluble sugars that can inhibit the cement cure (VAICKELIONIS \& VAICKELIONIENE, 2003). When $\mathrm{Ca}(\mathrm{OH})_{2}$ solution was added at the woodcement mixture, a possible degradation could occur inside the composite and the total amount of formed sugars could negatively affect the cement hardening. For composites treated with $\mathrm{CaCO}_{3}$, the degradation occurred partially during the carbonatation time and part of the reaction formed sugars weren't added to the mixture.

The average internal bond values reported at G1 particles specimens were higher that the minimum requirement of $0.4 \mathrm{MPa}$ for woodcement boards established by BISON process (NCL INDUSTRIES LTD., 2011).
There was no statistically difference for mechanical properties of modulus of rupture and modulus of elasticity between composites produced with the same particles size. Composites produced with $\mathrm{G} 1$ particles and pretreated with $\mathrm{Ca}(\mathrm{OH})_{3}$ demonstrated average MOR values statistically higher than composites produced with G2 particles and same pretreatment.

For both bending properties, MOR and MOE, all the average values were lower than the minimum BISON requirement (9.0MPa and 3,000MPa, respectively) (NCL INDUSTRIES LTD., 2011). However, it is important to consider the difference between the specific gravity between vibro-compaction composites and commercial wood-cement boards. The minimum requirements suggested for BISON process composites are suggested for wood-cement board with minimum specific gravity of $1,100 \mathrm{~kg} \mathrm{~m}^{-3}$. The average specific gravity of the specimens produced with the new methodology was $640 \mathrm{~kg} \mathrm{~m}^{-3}$.

It was also noticed that the general quantity of water used in the mixtures wasn't enough, the equation used to calculate the amount of water was suggested by SIMATUPANG (1979). The formula considered an extra water content present at the wood particles that is liberated when the composite is pressed. As there is no pressure applied at the vibro-compaction method, it is necessary an adjustment to the equation to allow the mixture of enough water to promote the cement cure.

Table 3 - Physical and mechanical properties of wood-cement composites.

\begin{tabular}{|c|c|c|c|c|c|}
\hline Particles size & Treatment & Specific gravity $\left(\mathrm{kg} \mathrm{m}^{-3}\right)$ & $\operatorname{MOR}(\mathrm{MPa})$ & $\operatorname{MOE}(\mathrm{MPa})$ & IB (MPa) \\
\hline \multirow{3}{*}{ G1 } & $\mathrm{CS}$ & $610^{\mathrm{bA}}$ & $0.27^{\mathrm{aA}}$ & $336.65^{\mathrm{aA}}$ & $0.96^{\mathrm{aA}}$ \\
\hline & $\mathrm{CaCO}_{3}$ & $610^{\mathrm{bA}}$ & $0.41^{\mathrm{aA}}$ & $310.19^{\mathrm{aA}}$ & $0.74^{\mathrm{aA}}$ \\
\hline & $\mathrm{Ca}(\mathrm{OH})_{2}$ & $690^{\mathrm{aA}}$ & $0.37^{\mathrm{aA}}$ & $300.70^{\mathrm{aA}}$ & $1.65^{\mathrm{bA}}$ \\
\hline \multirow{3}{*}{ G2 } & CS & $600^{\mathrm{bA}}$ & $0.15^{\mathrm{aA}}$ & $205.73^{\mathrm{aA}}$ & $0.21^{\mathrm{bB}}$ \\
\hline & $\mathrm{CaCO}_{3}$ & $630^{\mathrm{bA}}$ & $0.31^{\mathrm{aA}}$ & $361.67^{\mathrm{aA}}$ & $0.34^{\mathrm{aB}}$ \\
\hline & $\mathrm{Ca}(\mathrm{OH})_{2}$ & $700^{\mathrm{aA}}$ & $0.16^{\mathrm{aB}}$ & $395.92^{\mathrm{aA}}$ & $0.28^{\mathrm{bB}}$ \\
\hline
\end{tabular}

Where: ${ }^{*} \mathrm{G} 1$ and G2, particles size; MOR, modulus of rupture; MOE, modulus of elasticity; IB, internal bond; and CS, control specimens. ${ }^{* *}$ Average values followed by same small caps letter, in the same row, are statistically equals at $5 \%$ significance, for composites produced with different particles size; ${ }^{* * *}$ Average values followed by same caps lock letter, in the same row, are statistically equals at $5 \%$ significance, for composites produced with different pre-treatment. 


\section{CONCLUSION}

The vibro-compaction densification method was viable for manufacture of wood-cement composites with low specific gravity (lower then $\left.1,100 \mathrm{~kg} \mathrm{~m}^{-3}\right)$. The average values of mechanical properties MOR and MOE weren't enough to reach the minimal requirements, and for that reason, the material can't be applied for structural uses, but the low specific gravity and internal bond values higher than the minimum requirement suggested that woodcement composites produced by vibro-compaction densification have potential use as filling materials for construction.

Wood particle sizes is an essential characteristic for production by vibro-compaction densification. Among the two particles size studied at 2:1 cement: wood ratio, it is recommended the use of particles that pass through $4 \mathrm{~mm}$ sieve and collected at $2 \mathrm{~mm}$ sieve.

The use of lime as wood particle pretreatment is a possible procedure to minimize the inhibitor effect of wood at the cement cure. Calcium hydroxide solution applied direct to the mixture contributed to the production of composites with higher specific gravity and internal bond values.

\section{ACKNOWLEDGEMENTS}

The authors are grateful for the support of the Conselho Nacional de Desenvolvimento Científico e Tecnológico $(\mathrm{CNPq})$ and the Coordenação de Aperfeiçoamento de Pessoal de Nível Superior (CAPES).

\section{REFERENCES}

ABRAF. Anuário estatístico da ABRAF 2010: ano base 2009 Brasília, 2010. 140p.

ADEFISAN, O.O. et al. Effects of particle size, composite mix and cold water treatment on the compressive strength of Eremospatha macrocarpa-cement composite. Journal of tropical forest science, v.24. n.3, p.344-347, 2012. Available from: <http://www.jstor.org/ stable/pdf/23617118.pdf $>$. Accessed: Apr. 15, 2017.

ANGST, U. et al. Critical chloride content in reinforced concrete - a review. Cement and concrete research, v.39, p.1122-1138, 2009 Available from: <http:/www.sciencedirect.com/science/article/pii/ S0008884609002099>. Accessed: Apr. 15, 2017. doi: 10.1016/j. cemconres.2009.08.006.

ASSOCIAÇÃO BRASILEIRA DE NORMAS TÉCNICAS. NBR 6118: Projeto de estruturas de concreto - procedimento. 2003. 221p.

DAL RI, M. Efeitos da adição de cal hidratada em concretos com altos teores de adição mineral na penetração de cloretos e na solução aquosa dos poros de concreto. 2002. 111f. Dissertação (Mestrado em Engenharia Civil) - Programa de Pós-graduação em Engenharia Civil, Universidade Federal de Santa Maria, RS.
Available from: < http://w3.ufsm.br/gepecon/diss/6139fe04974850 321553f3ac55ebcea2.pdf>. Accessed: Apr. 15, 2017.

EUROPEAN COMMITTEE FOR STANDARDIZATION (CEN). EN 310. Wood-based panels - Determination of modulus of elasticity in bending and of bending strength. Brussels, Belgium. 1993. 14p.

\section{EUROPEAN COMMITTEE FOR STANDARDIZATION (CEN).} EN 319. Aglomerado de partículas de madeira e aglomerado de fibras de madeira - determinação da força da tensão perpendicular sobre a superfície plana da placa. Brussels, Belgium. 1993. 6p.

FRYBORT, S. et al. Cement bonded composites: a mechanical review. BioResources, v.3, n.2, p.602-626, 2008. Available from: <https:// ojs.cnr.ncsu.edu/index.php/BioRes/article/view/BioRes_03_2_0602_ CementBondedComposites/205>. Accessed: Apr. 15, 2017.

KARADE, S. et al. Influence of granule properties and concentration on cork-cement compatibility. Holz als roh- und werkstoff, v.64, p.281-286, 2006. Available from: <https://link.springer.com/ article/10.1007\%2Fs00107-006-0103-2?LI=true >. Accessed: Apr. 15, 2017. doi: 10.1007/s00107-006-0103-2.

NAZERIAN, M. et al. Effects of wood species, particle sizes and dimensions of residue obtained from trimming of wood-cement composites on physical and mechanical properties of cement-bonded particleboard. Wood Material Science and Engineering, v.6, p.196206, 2011. Available from: <http://dx.doi.org/10.1080/17480272.2011.6 01816>. Accessed: Apr. 15, 2017. doi: 10.1080/17480272.2011.601816.

NCL INDUSTRIES LTD. Bison panel - Cement bonded particle board. Abids, 2011. 24p.

OLORUNNISOLA, A.O. Effect of husk particle size and calcium chloride on strength and sorption properties of coconut husk-cement composites. Industrial Crops and Products, v.29, p.495-501, 2009. Available from: $<$ http://www.sciencedirect.com/science/article/pii/S0926669008001970>. Accessed: Apr. 15, 2017. doi: 10.1016/j.indcrop.2008.09.009.

PARCHEN, C.F.A. Compósito madeira cimento de baixa densidade produzido com compactação vibro dinâmica. 2012. 172f. Tese (Doutorado em Ciências Florestais) - Programa de Pós-graduação em Engenharia Florestal, Universidade Federal do Paraná, PR.

SIMATUPANG, M.H. Der wasserbedarf bei der herstellung zementgebunder holzspanplatten. Holz als Roh-und Werkstoff, v.27, p.379-382, 1979.

VAICKELIONIS, G.; VAICKELIONIENE, R. The influence of organic and mineral additives on hydration of cement. Medziagotyra, v.9, n.3, p.218-223, 2003. Available from: <http://internet.ktu.lt/lt/ mokslas/zurnalai/medz/pdf/medz0_73/14\%20Vaickelionis\%20(218223).pdf $>$. Accessed: Apr. 15, 2017.

WEI, Y. M. et al. Study of hydration behavior of wood cementbased composite II: effect of chemical additives on the hydration characteristics and strengths of wood-cement composites. Journal of wood science, v.46, p.444-451, 2000. Available from: $<$ https://ink. springer.com/article/10.1007/BF00765802>. Accessed: Apr. 15, 2017. doi: $10.1007 / \mathrm{BF} 00765802$

WOLFE, R.W.; GJINOLLI, A. Cement-bonded wood composites as an engineering material. In: THE USE OF RECYCLED WOOD AND PAPER IN BUILDING APPLICATIONS, 1996, Madison, USA. Proceedings... Madison: Forest Products Society, 1997. p.84-91. 